\author{
Muthana Mohammad Omoush \\ PhD (Economics), Associate Professor of the Department of Tourism Management, \\ Dean of the Faculty of Administrative Science and Finance \\ e-mail: muthana-tourism@hotmail.com, ORCID ID: https://orcid.org/0000-0002-6401-3877 \\ Irbid National University, PO Box 2600, Irbid, 21110, Jordan

\section{IMPACT KNOWLEDGE MANAGEMENT ON INNOVATION. FIELD STUDY ON TOURIST AGENCIES IN IRBID CITY, JORDAN}

This article is dealt with investigate the impact knowledge management process, knowledge creation, knowledge sharing, knowledge application and knowledge storage, an innovation. Accordingly, a questionnaire-based survey was designed to test the aforementioned model based on dataset of 122 employees' from the agency traveling in Jordan. Following the analytical descriptive methodanalyzed the relationship between the independent variable (knowledge management process) and the dependent variable (innovation), aims to know the effect of the independent variable on the dependent variable. In order, to achieve the objective of the study, a 24-question questionnaire was developed to collect primary information from the study community, and then analyzed using SPSS V 22, multiple regression were conducted to test the article`s hypotheses.

The results indicated that knowledge process (knowledge creation, knowledge sharing, and knowledge storage) positively and significantly affect innovation. However, knowledge application insignificantly effect in innovation, and these results are in agree with the results of the previous literature. The results have enormous implication for the agency traveling in Jordan. The study provided a group of recommendations to speed up adopting the knowledge management in agency traveling in Jordan, the results of this study suggest that firms can be better off, in terms of innovation performance, if they are based on the incentive / compensation system for knowledge activities. When traditional economic figures are replaced by indicators such as knowledge creation, participation and utilization, staff will most likely work with these activities and thereby improve the performance of the company's full innovation.

Keywords: knowledge management, knowledge creation, knowledge sharing, knowledge application, knowledge storage and innovation.

Мутана Мохаммад Омуш. ВПЛИВ УПРАВЛІННЯ ЗНАННЯМИ НА ІННОВАЦІЇ. ПОЛЬОВЕ ДОСЛДЖЕННЯ ТУРИСТИЧНИХ АГЕНТСТВ У МІСТІ ІРБІД, ЙОРДАНІЯ

Ця стаття присвячена вивченню впливу процесу управління знаннями, створення знань, обміну знаннями, застосування знань і зберігання знань, інновацій. Відповідно, було проведено анкетування для перевірки згаданої вище моделі, заснованої на наборі даних $з$ опитування 122 співробітників туристичних агентств в Йорданії. Дотримуючись аналітичного описовому методу, проводиться аналіз зв'язку між незалежною змінною (процес управління знаннями) і залежною змінною (інновація), метою якого є визначення впливу незалежної змінної на залежну. Щоб досягти мети дослідження, була розроблена анкета $з 24$ питань для збору первинної інформації від досліджуваної групи, а потім проаналізовано 3 використанням SPSS V 22, була проведена множинна регресія для перевірки гіпотез статті.

Результати показали, що процес знань (створення знань, обмін знаннями та зберігання знань) позитивно і суттєво впливає на інновації. Однак застосування знань майже не позначається на інноваціях, і ці результати узгоджуються 3 результатами аналізу наукової літератури. Результати мають велике значення для туристичних агентств в Йорданії. Дослідження надало низку рекомендацій щодо прискорення впровадження управління знаннями в туристичних агентствах Йорданії. Результати цього дослідження показують, що фірмам може бути краще 3 точки зору ефективності інновацій, якщо вони засновані на системі мотивації / компенсації за діяльність у сфері створення знань. Коли традиційні економічні показники замінюються такими індикаторами як створення знань, участь і використання, співробітники, швидше за все, будуть працювати з цими видами діяльності і, таким чином, покращувати ефективність усіх інновацій компанії. вації.

Ключові слова: управління знаннями, створення знань, обмін знаннями, застосування знань, зберігання знань, інно-

Мутана Мохаммад Омуш. ВЛИЯНИЕ УПРАВЛЕНИЯ ЗНАНИЯМИ НА ИННОВАЦИИ. ПОЛЕВОЕ ИССЛЕДОВАНИЕ ТУРИСТИЧЕСКИХ АГЕНТСТВ В ГОРОДЕ ИРБИД, ИОРДАНИЯ

Эта статья посвящена изучению влияния процесса управления знаниями, создания знаний, обмена знаниями, применения знаний и хранения знаний, инноваций. Соответственно, было проведено анкетирование для проверки вышеупомянутой модели, основанной на наборе данных из опроса 122 сотрудников туристических агентств в Иордании. Следуя аналитическому описательному методу, проводится анализ связи между независимой переменной (процесс управления знаниями) и зависимой переменной (инновация), целью которого является определения влияния независимой переменной на зависимую. Чтобы достичь цели исследования, была разработана анкета из 24 вопросов для сбора первичной информации от исследуемой группы, а затем проанализирована с использованием SPSS V 22, была проведена множественная регрессия для проверки гипотез статьи.

Результаты показали, что процесс знаний (создание знаний, обмен знаниями и хранение знаний) положительно и существенно влияет на инновации. Однако применение знаний незначительно сказывается на инновациях, и эти результаты согласуются с результатами анализа научной литературы. Результаты имеют большое значение для туристических агентств в Иордании. Исследование предоставило ряд рекомендаций по ускорению внедрения управления знаниями в туристических агентствах Иордании. 
Результаты этого исследования показывают, что фирмам может быть лучше с точки зрения эффективности инноваций, если они основаны на системе мотивации / компенсации за деятельность в области создания знаний. Когда традиционные экономические показатели заменяются такими индикаторами как создание знаний, участие и использование, сотрудники, скорее всего, будут работать с этими видами деятельности и, таким образом, улучшать эффективность всех инноваций компании.

Ключевые слова: управление знаниями, создание знаний, обмен знаниями, применение знаний, хранение знаний, инновации.

Introduction. Technological development changes the dynamics within the organizations' environment, an uncertain and rapidly changing environment. The faster this change is, the more important the innovation [1]. Rapid technological changes, more sophisticated customers, and the importance of innovation have transformed the competitive foundations of many companies away from traditional material and financial resources into intellectual assets. Thus, there is widespread recognition that intellectual assets (strategic resources) are a critical force driving business growth [7]. New technologies have contributed to changing consumption and production patterns, which also affect changes in firms and products [2]. These changes require efforts by organizations that need to monitor and access various sources of knowledge within and outside the organization, such as employees, customers, suppliers and competitors, to incorporate that knowledge. To add value and influence innovation, and to monitor the development of new markets and challenges [3, 2].

Knowledge Management (KM) has become one of the most important and exciting concepts in management. Knowledge becomes increasingly important as part of organizational assets because it has a positive impact on gaining competitive advantage and improving innovation that leads the organization to superior performance. Successful companies must acquire the ability to collect, store and distribute specialized knowledge in order to create and sustain a competitive advantage [5]. The company's ability to innovate is linked to the knowledge it possesses or acquires and how it organizes itself to work with that knowledge [4].

Although many studies have found a positive impact, knowledge management (innovation) [5, 6], but the rare studies that have investigated this relationship in Jordan, and in the tourism sector (tourist agencies), in particular, examine this research. The gaps in the investigation of these relations in the tourism sector (tourist agencies in the city of Irbid. This sector is chosen because it has become one of the most important pillars supporting the country's economy through the development of tourism products and services and stimulate investment and labor market (www.mota.gov.jo). Although it has seen many developments and increased numbers of tourism agencies, are considered relatively weak in innovation, especially in the process of customer interaction through its weakness in the development of tourism products and services.

Theoretical framework knowledge management. One of the main characteristics of this century is that it is an age of knowledge, where knowledge becomes an important asset that organizations can use to increase the process of innovation and gain their competitive advantage by considering every person in the organization that he knows and how they use their knowledge [8]. Knowl- edge has become one of the most important factors of production with human resources and capital, the main engine of economic growth and the catalyst for technology development and production promotion; knowledge creates innovation and then transforms into processes and products [9].

KM's main objective is to provide knowledge to the organization on an ongoing basis and to make it a practical position that serves the organization's objectives to achieve efficiency and effectiveness through planning and organizing knowledge efforts to achieve the strategic and operational objectives of the organization [9]. Knowledge management also enables enterprises to transform information and data into relevant knowledge that meets organizational objectives [12]. People, as well as processes and techniques associated with knowledge management, are key factors in knowledge management. Knowledge management revolves around managing relationships between people and how organizational structures, leadership and culture affect people who carry out knowledge management processes as part of their work [12]. Help organizations find new ways to use implicit and explicit individual knowledge. It also collects the knowledge, rational capacities and experience of people working in the organization, and the ability to retrieve them as assets of the organization [23].

Knowledge Management (KM) is defined as the sum of systematic processes that assist the organization in generating, producing, organizing, employing, disseminating and making available knowledge to all Members and beneficiaries of the Organization [10]. Knowledge management is an ongoing process involving many activities and practices aimed at identifying, generating, developing, disseminating, implementing, conserving and facilitating retrieval, thereby positively impacting performance improvement, reducing costs and improving capacity to adapt to the requirements for rapid and continuous change in the environment surrounding the organization [11]. While [23] considers that KM is a way of building a learning organization where employees can generate, share, create, apply and save them in their decision-making activities, KM is a knowledge of when and where a person may need them and how to access them.

Knowledge management processes are a coherent, continuous and dynamic process involving the generation, sharing, storage, retrieval and application of knowledge [12]. This paper focuses on four basic processes of knowledge management: knowledge creation, knowledge sharing, application of knowledge and knowledge storage. Knowledge creation, Nonaka et al. (2000), pointed out. That knowledge generation is an organizational, social and collaborative process of interactions between explicit and implicit knowledge, rather than merely implicit or explicit knowledge. 
Knowledge sharing can be defined as a social interaction culture, which shows the exchange of people's knowledge, experience and skills throughout the entire organization [13]. Application knowledge, can be considered as a process of transferring ideas, skills and experiences to practices that lead to improved organizational performance. This makes knowledge value-added that contributes to changing the nature of the organization's work and development. And to make knowledge linked to the concept of organizational learning that is capable of recording and documenting knowledge gained through experience and expertise and making it available to others [4]. Knowledge storage processes aim to maintain knowledge and facilitate its application and use within organizations, including activities designed to transform, document, organize, and maintain knowledge [14]. This process is used to address inconsistencies [1].

Knowledge management and innovation. Knowledge management not only focuses on innovation, but creates an environment conducive to innovation, and the organization's ability to innovate depends on its internal competencies, such as its knowledge .It also depends on its skills in finding, adopting and expanding the knowledge it generates as well as its interactions with the surrounding environment. Based on the fact that innovation is an essential and interactive process that results from many parties who participate directly or indirectly by adding their specific knowledge, initiatives and competencies [5]. Knowledge is learned and exploited to improve business and innovation. In addition, organizations can stimulate generation, application sharing and knowledge dissemination to facilitate innovation as knowledge management has a positive impact and its contribution to transforming implicit knowledge into innovative products, services and processes that improve innovative performance [15]. In the long term, companies that create new knowledge at a lower cost and more quickly that competitors, and then apply that knowledge effectively and efficiently, will succeed in creating innovation-based products and services that will give them a competitive advantage [3]. Several empirical studies have examined the impact of different aspects of knowledge-based assets, especially knowledge management, on the performance of innovation.

These studies have shown that knowledge processes - such as knowledge creation and participation, application, documentation and storage - have a positive impact on the company's innovation performance [16, 17, 23]. There was a link between knowledge sharing and innovation as when firms encourage employees to disseminate knowledge within groups and organizations, which will enhance their ability to generate and create new ideas and opportunities. And the exchange of technological knowledge among competitors will lead to higher creative performance than those who do not share knowledge. Thus, knowledge sharing (knowledge transfer) is essential for all organizations.

Methodology and Procedures. For the purpose of achieving the objectives of the study, the study adopted descriptive research methodology and analytical field research. At the descriptive research level, the Bureau's survey was conducted; theoretical and field studies and research in literature were examined to develop the basis and starting points of the theoretical framework. At the level of field analytical research, the survey was conducted on a sample of the study population who were asked to answer the questionnaire sections designed for this study. Subsequently, the data were analyzed through a questionnaire using the Statistical Package for Social Sciences (SPSS) program. (After analyzing the data and drawing the preliminary results, hypotheses of the study, which were developed for the purpose of achieving the objectives of the study.

Study Model. Based on the literature review, our theory model, as presented in Figure 1, considers the interrelationships among Knowledge Management Process (KM P), (KC,KS,KA,KST), and Innovation (INN). We discuss the theory model for developing research hypotheses in the following subsections.

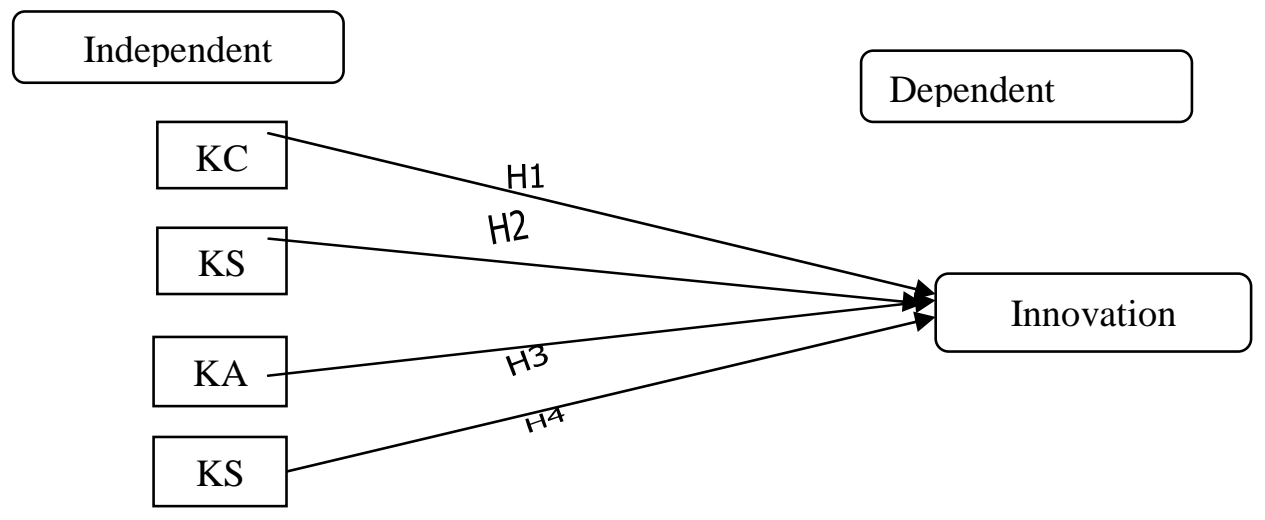

Fig. 1. Research model

Study Hypothesis. The study mainly aimed to test the impact of Knowledge management (KC, KS, KA, KST) on Innovation. Therefore, the main hypothesis is:

$\mathrm{H}: 1$ There is no impact with statistical significant at $(\alpha \leq 0.05)$ of Knowledge creation on Innovation.
$\mathrm{H}: 2$ There is no impact with statistical significant at $(\alpha \leq 0.05)$ of Knowledge sharing on Innovation.

$\mathrm{H}: 3$ There is no impact with statistical significant at $(\alpha \leq 0.05)$ of Knowledge application on Innovation.

$\mathrm{H}: 4$ There is no impact with statistical significant at 
( $\alpha \leq 0.05)$ of Knowledge storage on Innovation.

Study Population and Sample. The study population consisted of the traveling agency in Irbid Governorate in all senior, middle and lower administrative levels. Sample was taken from all employees in the agencies in Irbid Governorate. Approximately 150 questionnaires were distributed. About 134 questionnaires were retrieved. About 12 questionnaires were excluded due to non-validity of the statistical analysis, so that the questionnaires valid for analysis would become 122 questionnaires.

Respondents Demographic Profile. As indicated in Table 1, the demographic profile of the respondents for this study shows that, the proportion of males is more than females .Most respondents hold a Bachelor degree $(89.6 \%), 42.5 \%$ considered as middle level management, and $60.5 \%$ of them have experience between 5-less than 10 years.

Description of the respondents' demographic profiles

Table 1

\begin{tabular}{|c|c|c|c|}
\hline Demographics & Category & Frequency & Percentage \% \\
\hline Gender & Males & 84 & 65.7 \\
\hline & Female & 38 & 34.3 \\
\hline & Total & $\mathbf{1 2 2}$ & $\mathbf{1 0 0}$ \\
\hline Qualification & High school or less & 12 & 10.4 \\
\hline & Bachelor & 110 & 89.6 \\
\hline & Total & $\mathbf{1 2 2}$ & $\mathbf{1 0 0}$ \\
\hline Position & Low level management & 60 & 55.0 \\
\hline & Middle level management & 56 & 42.5 \\
\hline & Top level management & 4 & 2.5 \\
\hline Years of experience & Total & $\mathbf{1 2 2}$ & $\mathbf{1 0 0}$ \\
\hline & Less than 5 years & 35 & 39.5 \\
\hline & $5-$ less than 10 years & 87 & 60.5 \\
\hline & Total & $\mathbf{1 2 2}$ & $\mathbf{1 0 0}$ \\
\hline
\end{tabular}

Instrument Validity. The questionnaire was presented to a group of professors and specialists in the field of administrative sciences to express their opinion therein. Whereas the suggestions and recommendations received from them regarding the phrases thereof have been taken. The necessary amendments have been conducted to the paragraphs of the study. Some of the paragraphs of the study have been rewritten and reformulated.

Instrument Reliability. For measuring the study tool reliability (questionnaire), the reliability coefficient (Cronbach Alpha) has been used to show the extent of the internal consistency of the phrases forming the standards which were adopted by the study, as the results indicate that the reliability coefficient of all dimensions not less than (0.60). The reliability coefficient of all the paragraphs of the questionnaire was $(0.81)$. This means that the

Hypotheses Testing. The study hypotheses were tested by using simple and multiple linear regression. The main hypotheses are: there is no impact with statistical significant at $(\alpha \leq 0.05)$ of knowledge management (KC, KS, KA, KST) on Innovation.

\section{Results of multiple regression analysis to the impact of knowledge management}

\begin{tabular}{|c|c|c|c|c|}
\hline Variable & $(\mathbf{B})$ & $(\boldsymbol{\beta})$ & $(\mathbf{T})$ & p-value \\
\hline Knowledge creation & 0.265 & 0.146 & 3.224 & 0.000 \\
\hline Knowledge sharing & 0.273 & 0.235 & 3.872 & 0.001 \\
\hline Knowledge application & 0.259 & 0.367 & 3.721 & 0.0460 \\
\hline Knowledge storage & 0.423 & 0.345 & 4.754 & 0.000 \\
\hline R & \multicolumn{3}{|c|}{0.652} \\
\hline R2 & \multicolumn{3}{|c|}{0.442 .174} \\
\hline F & \multicolumn{3}{|c|}{000} \\
\hline P-value & \multicolumn{5}{|c|}{} \\
\hline
\end{tabular}

Table 2 shows us the results of multiple regression analysis to the impact of knowledge management with its four dimensions as independent variable in the innovation. Table 2 shows that the value of the coefficient of determination is (R2 0.442). This explains a percentage of $(44.2 \%)$ of the impact of knowledge management on innovation. The correlation coefficient has reached $(\mathrm{R}=$ $0.652)$, while the value is $(\mathrm{F}=42.174)$. The potential value was $(\mathrm{P}$-value $=0.000)$; thus, it is lower than the approved significance level (0.05). Accordingly, we reject the null hypothesis, which states that there is no statistically significant impact of knowledge management 
(Knowledge creation, Knowledge sharing, Knowledge application, Knowledge storage) on innovation. We accept alternative hypothesis, which states the presence of a statistically significant impact of all variable knowledge management on innovation.

Table 2 also shows the impact of each dimension of knowledge management on innovation. Where the results indicated that the dimensions that have a statistical significance and impact on innovation which is knowledge creation that reached $(\beta=0.146)$. This is a statistical significance, because the value is $(\mathrm{t}=3.224, \mathrm{P} \leq$ $0.05)$. The knowledge sharing which value has reached $(\beta=0.235)$, this is a statistical significance, because the value is $(\mathrm{t}=3.872, \mathrm{P} \leq 0.05)$. The Knowledge storage which value has reached $(\beta=0.345)$, this is a statistical significance, because the value is $(\mathrm{t}=4.754, \mathrm{P} \leq 0.05)$, while the results did not show any trace Knowledge application on innovation.

Discussion. The aim of this research is to investigate the interrelationships among Knowledge Management Process, innovation. The results of the direct effects show that Knowledge Management Process (Knowledge creation, knowledge sharing, knowledge application, knowledge sharing) is positively and significantly related to innovation. This result agrees with the findings of [18] (2010). They found a positive relationship between Knowledge Management Process and innovation [19], found that the institutionalized knowledge and codified experience (i.e. organizational capital) and the interaction-based knowledge among individuals and their networks (i.e. social capital) mediate the relationship between HRM practices and incremental innovative capability, whereas social capital acts as a mediator between HRM practices and radical innovative capability. Moreover, [20] I discovered that creative and skilled staff and experts (ie, human capital) complemented by well-organized networks for corporate clients (ie, client capital) are the key ingredients in achieving a high degree of creative performance [21]. The same trend of reflection continues with reference to staff skill levels, relative organizational learning capabilities (ie, human capital), structured knowledge embedded in processes and information systems (ie, structural capital), and degree. External integration with suppliers and customers (ie, social capital) is an important precedent for product innovation. Other researchers have found that organizational culture is an important enabling factor for behavior related to knowledge at work [22].

Implication. It seems that strategic planning, implementation and modernization of activities where knowledge is the key component is positively related to innovation. At the practical level, the knowledge management strategy revolves around assessing current knowledge and the need for future knowledge. Then, the KM strategy is formulated to bridge the gap between what already exists and what should be. It is equally important practice to communicate and disseminate strategy throughout the organization, to ensure that everyone works to achieve the common goal. Thus, the strategic knowledge management strategy supports innovation performance because it helps define the strategic knowledge gap that emphasizes the need to create knowledge and new knowledge flows.

Employees are usually compensated on the basis of their economic performance. For example, sales people receive rewards for achieving or exceeding specific sales quotas, and project managers are compensated for the pipeline projects to achieve their goals in terms of time and budget. However, the results of this study suggest that firms can be better off, in terms of innovation performance, if they are based on the incentive / compensation system for knowledge activities. When traditional economic figures are replaced by indicators such as knowledge creation, participation and utilization, staff will most likely work with these activities and thereby improve the performance of the company's full innovation.

\section{References:}

1. Teixeira, E.K., Oliveira, M., Curado, C.M. (2018). Knowledge management process arrangements and their impact on innovation. Business Information Review, 35(1), 29-38.

2. Bolisani, E., Bratianu, C. (2017). Knowledge strategy planning: an integrated approach to manage uncertainty, turbulence, and dynamics. Journal of Knowledge Management, 21(2), 233-253.

3. Dayan, R., Heisig, P, Matos, F. (2017). Knowledge management as a factor for the formulation and implementation of organization strategy. Journal of Knowledge Management, 21(2), 308-329.

4. Chawinga, W.D., Chipeta, G.T. (2017). A synergy of knowledge management and competitive intelligence: a key for competitive advantage in small and medium business enterprises. Business Information Review, 34(1), 25-36.

5. Bader Yousef Obeidat, Mai Maher Al-Suradi, Ra'ed Masa'deh, Ali Tarhini (2016). The impact of knowledge management on innovation: An empirical study on Jordanian consultancy firms. Management Research Review, 39(10), 1214-1238.

6. Sivalogathasan, V., Wu, X. (2015). Impact of Organization Motivation on Intellectual Capital and Innovation Capability of the Textile and Apparel Industry in Sri Lanka. International Journal of Innovation Science, 7(2), 153168 .

7. Kamukama, N., Ahiauzu, A., Ntayi, J.M. (2010). Intellectual capital and performance: testing interaction effects. Journal of Intellectual Capital, 11(4), 554-574.

8. Obeidat, B.Y., Al-Suradi, M., Masa'deh, R., Tarhini, A. (2016). The impact of knowledge management on innovation: An empirical study on Jordanian consultancy firms. Management Research Review, 39(10), 12141238.

9. Abualoush, S.H., Obeidat, A., Tarhini, A., Masa'deh, R., Al-Badi, A. (2018). The role of employees' empowerment as an intermediary variable between knowledge management and information systems on employees' performance. VINE Journal of Information and Knowledge Management Systems, 48(2), 217-237. 
10. Masa'deh, R. (2016). The role of knowledge management infrastructure in enhancing job satisfaction at Aqaba five star hotels in Jordan. Communications and Network, 8(4), 219-240.

11. Nonaka, I., Toyama, R., Konno, N. (2000). SECI, ba and leadership: a unified model of dynamic knowledge creation. Long Range Planning, 33(1), 5-34(24).

12. Fombad, M. (2018). Knowledge management for poverty eradication: a South African perspective. Journal of Information, Communication and Ethics in Society, 16(2), 193-213.

13. Lin, C.-P. (2007). To share or not to share: modeling tacit knowledge sharing, its mediators and antecedents. Journal of Business Ethics, 70(4), 411-428.

14. Nonaka, I, Byosiere, P, Borucki, C.C, et al. (1994). Organizational knowledge creation theory: a first comprehensive test. International Business Review, 3(4), 337-351.

15. Jimenez-Jimenez, D., Martinez-Costa, M., Sanz-Valle, R. (2014). Innovation, organizational learning orientation and reverse knowledge transfer in multinational companies. The Electronic Journal of Knowledge Management, 12(1), 47-55

16. Chen, C.-J., Huang, J.-W., Hsiao, Y.-C. (2010). Knowledge management and innovativeness: the role of organizational climate and structure. International Journal of Manpower, 31(8), 848-870.

17. Lee, V., Leong, L., Hew, T., Ooi, K. (2013). Knowledge management: a key determinant in advancing technological innovation? Journal of Knowledge Management, 17(6), 848-872(35).

18. Chen, C.-J., Huang, J.-W., Hsiao, Y.-C. (2010). Knowledge management and innovativeness: the role of organizational climate and structure. International Journal of Manpower, 31(8), 848-870.

19. Wang, D., Chen, S. (2013). Does intellectual capital matter? High-performance work systems and bilateral innovative capabilities. International Journal of Manpower, 34(8), 861-879.

20. Castro, G.M., Delgado-Verde, M., Amores-Salvadó, J., Navas-López, J.E. (2013). Linking human, technological, and relational assets to technological innovation: exploring a new approach. Knowledge Management Research \& Practice, 11(2), 123-132.

21. Menor, L.J., Kristal, M.M., Rosenzweig, E.D. (2007). Examining the influence of operational intellectual capital on capabilities and performance. Manufacturing and Service Operations Management, 9(4), 559-578.

22. Travica, B. (2013). Conceptualizing knowledge culture. Online Journal of Applied Knowledge Management, 1(2), 85-104.

23. Monavvarian, A., Khamda, Z. (2010). Towards successful knowledge management: people development approach. Business Strategy Series, 11(1), 20-42(29).

Надійшла до редколегї̈ 01.10.2018 р.

\section{Про автора:}

Мутана Мохаммад Омуш - PhD (Економіка), доцент кафедри менеджменту туризму, декан факультету управління і фінансів, Національний університет м. Ірбід, Йорданія, muthana-tourism@ hotmail.com, https://orcid.org/0000-0002-6401-3877

\section{Об авторе:}

Мутана Мохаммад Омуш - PhD (Экономика), доцент кафедры менеджмента туризма, декан факультета управления и финансов, Национальный университет г. Ирбид, Иордания, muthana-tourism@hotmail.com, https://orcid.org/0000-0002-6401-3877 